\title{
Nature of mononuclear cells positive for acid phosphatase activity in bone marrow of patients with renal osteodystrophy
}

\author{
M KAYE, JANET HENDERSON \\ From the Division of Nephrology, Montreal General Hospital, Montreal, Quebec, Canada
}

SUMMARY Fifty two of 63 patients with renal osteodystrophy had one or more mononuclear cells positive for acid phosphatase in the marrow. These cells are also tartrate resistant and non-specific esterase negative, and are believed to be precursors to osteoclasts and other acid phosphatase positive cells resorbing bone on the trabecular surface.

Osteoclasts are generally considered to derive from fusion of specialised mononuclear precursors, although there is some evidence that both mononuclear and multinuclear cells may have similar properties and help to resorb bone. ${ }^{1-9}$ Both types are associated with resorption bays (Howship's lacunae) and contain tartrate resistant acid phosphatase. The origin of these cells remains unclear but they are presumed to derive from precursors in the marrow, with recruitment determined by stimuli associated with the demand for bone resorption.

While examining sections from human iliac crest biopsy specimens from patients with renal failure it became apparent that mononuclear cells positive for acid phosphatase were seen not only against the bone surface but were also prominent within the marrow spaces (figure). This study was undertaken to assess the clinical importance of these cells.

\section{Material and methods}

Percutaneous anterior iliac crest biopsy specimens were obtained from patients receiving long term dialysis. The samples were processed as described previously, ${ }^{9}$ with fixation in $5 \%$ phosphate buffered formalin containing $0.25 \%$ sucrose, emedding in glycol and methyl methacrylate and cut into $2 \mu \mathrm{m}$ sections using a Porter-Blum microtome and glass knives. The sections were stained by acid phosphatase using napthol AS-TR phosphate as substrate and then counterstained with Harris's haematoxylin. ${ }^{9}$ Tartrate sensitivity was tested using 50 and $100 \mu \mathrm{M}$ sodium tartrate in the incubation medium, ${ }^{10}$ and non-specific esterase was looked for in freshly processed samples using standard techniques."

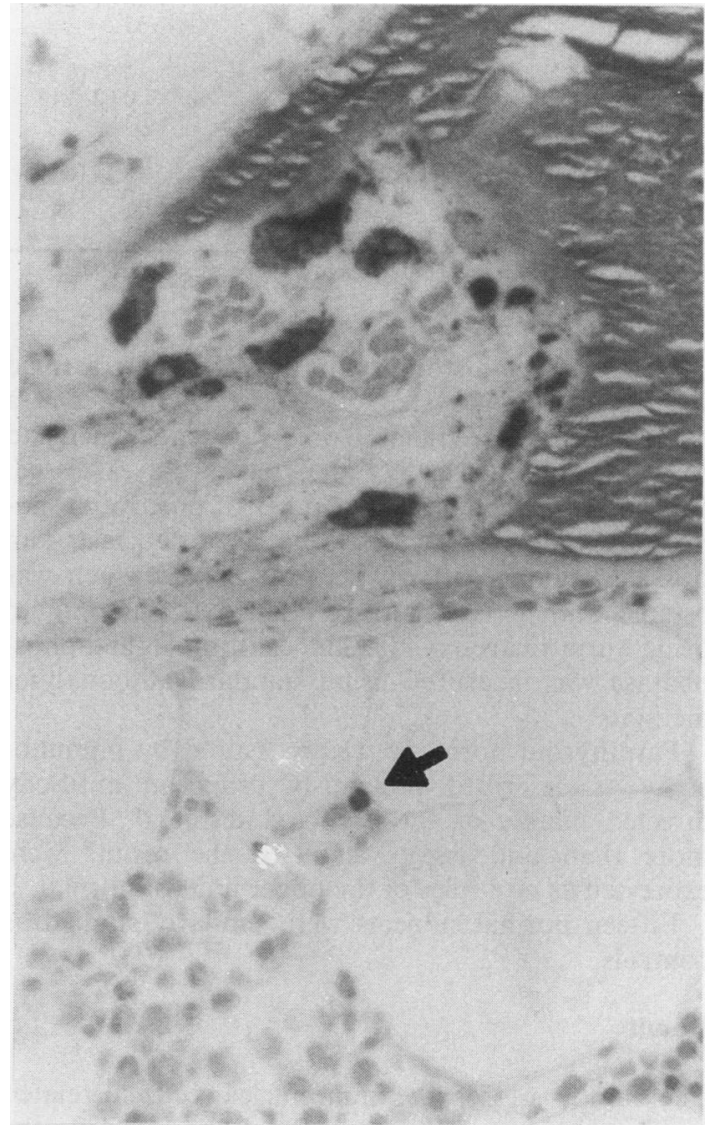

Figure Area of bone (top) undergoing resorption with numerous osteoclasts which appear dark in reproduction and are bright red in original due to their acid phosphatase content. In marrow space on right (arrow) one acid phosphatase cell is seen. 
Table Correlation coefficient $(r)$, significance $(p)$, and number $(n)$ in each group of variables

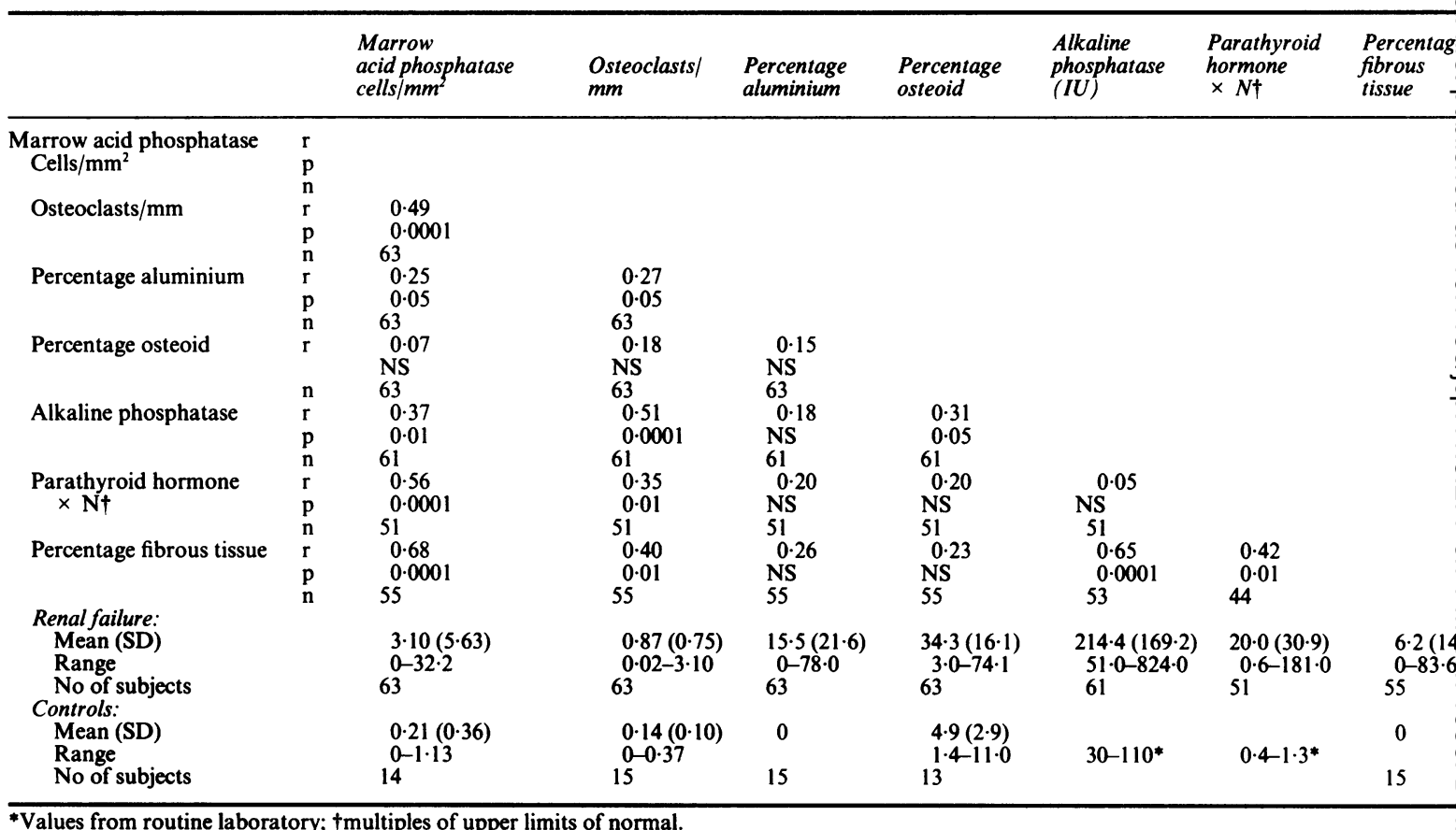

Quantitative histomorphometry was performed with a projection system, the Zeiss MOP-3, and a digitiser tablet. Specimens from 63 patients which had been morphometrically analysed were assessed. Results were expressed as number of positive mononuclear cells $/ \mathrm{mm}^{2}$ marrow area, osteoclasts $/ \mathrm{mm}$ trabecular bone surface, percent surface which was osteoid and percent surface stained for aluminium using aurintricarboxylic acid. ${ }^{12}$ Serum alkaline phosphatase was measured using standard autoanalyser methods.

Parathyroid hormone was measured by immunoassay as described previously using an antibody directed mainly at the carboxyl terminal. Because more than one assay was used the results were expressed as multiples of the upper limit of normal. ${ }^{13}$

Fifteen normal subjects were similarly studied as controls.

\section{Results}

The number of positive mononuclear cells correlated highly with osteoclasts on the bone surface, the activity of alkaline phosphatase, parathyroid hormone, and marrow fibrosis (table). Variables unrelated to parathyroid activity such as osteoid and aluminium surface did not show any positive correla- tion. The phosphatase positive cells were tartrate resistant and negative for non-specific esterase.

\section{Discussion}

These findings show that mononuclear cells positive for acid phosphatase are related primarily to secondary hyperparathyroidism. Osteoblastic surface was not measured but probably would also have been similarly related. It is unlikely that these cells are of the monocyte/macrophage type because of their staining characteristics and association with parathyroid hormone.

What is their function? They are probably cells being transported to the trabecular surface from marrow precursors towards an area of bone resorption. The more numerous the resorptive sites the more acid phosphatase cells are seen, presumably because the need for recruitment increases. It is impossible to conclude from these data whether the acid phosphatase cells are joining mononucleated or multinucleated cells, or both.

We thank L Malynowski for her expert technical help in preparing the bone sections and $\mathrm{H}$ Esposito for secretarial assistance. This work was supported by the Kidney Foundation of Canada (7-06-516). 


\section{References}

1 Chambers TJ. Multinucleate giant cells. J Pathol 1978;126:125-48.

2 Hanaoka H. The origin of the osteoclast. Clin Orthopaed 1979;145:252-63.

3 Teitelbaum SL, Kahn AJ. Mononuclear phagocytes, osteoclasts and bone resorption. Miner Electrolyte Metab 1980;3:2-9.

4 Marks SC Jr, Walker DG. The hematogenous origin of osteoclasts: experimental evidence from osteopetrotic (microphthalmic) mice treated with spleen cells from beige mouse donors. Am $J$ Anat 1981;161:1-10.

5 Loutit JF, Nisbet NW. The origin of osteoclasts. Immunobiol 1982;161:193-203.

6 Horton MA, Rimmer EF, Lewis D, Pringle JAS, Fuller K, Chambers TJ. Cell surface characterization of the human osteoclast: phenotypic relationship to other bone marrowderived cell types. J Pathol 1984;144:281-94.

7 Underwood JCE. From where comes the osteoclast? J Pathol 1984;144:225-6.

8 Minkin C, Shapiro IM. Osteoclasts, mononuclear phagocytes, and physiological bone resorption. Calcif Tissue Int 1986;39:357-9.
9 Kaye M. When is it an osteoclast? J Clin Pathol 1984;37:398-400.

10 Hammarstrom LE, Anderson TR, Marks SC Jr, Toverud SU. Inhibition of dithionite and reactivation by iron of the tartrateresistant acid phosphatase in bone of osteopetrotic (ia) rats. $J$ Histochem Cytochem 1983;31:1167-74.

11 Hermanns W. Identification of osteoclasts and their differentiation from mononuclear phagocytes by enzyme histochemistry. Histochem 1987;86:225-7.

12 Buchanan MRC, Ihle BU, Dunn CM. Haemodialysis related osteomalacia: a staining method to demonstrate aluminium. $J$ Clin Pathol 1981;34:1352.

13 Kaye M, Zucker SW, Leclerc YG, Prichard S, Hodsman AB, Barre P-E. Osteoclast enlargement in endstage renal disease. Kidney Int 1985;27:574-81.

Requests for reprints to: Dr M Kaye, Division of Nephrology, Montreal General Hospital, 1650 Cedar Avenue, Montreal, Quebec H3G 1A4, Canada. 